\title{
STUDI EKSPERIMEN PERILAKU STRUKTUR PERKERASAN KAKU
}

\author{
Iman Ruchiyat \\ Dosen Teknik Sipil Jurusan Teknik Sipil, Politeknik Negeri Bandung, Bandung 40012 \\ Email:Imanruchiyat@gmail.com
}

\begin{abstract}
ABSTRAK
Ruas jalan Tol Purbaleunyi khususnya Km 78+200 yang dijumpai beberapa pelat beton yang mengalami kerusakan terutama jenis kerusakan retak memanjang, retak melintang dan retak sudut yang menerus dari permukaan sampai dasar pelat beton. Perbaikan terhadap jenis kerusakan tersebut adalah dengan mengganti pelat beton/ full depth repair dengan pelat beton yang baru.Penelitian ini bertujuan untuk mengkaji perilaku pelat beton sebagai suatu bagian dari suatu struktur perkerasan kaku yang diletakan diatas berbagai variasi tanah dasar yang sudah mengalami stabilisasi termasuk tanah dasar eksisting. Perilaku struktur perkerasan diperlihatkan oleh kinerja struktural yaitu penurunan/ lendutan, regangan dan beban maksimum pada saat pelat beton tersebut mengalami kehancuran. Hasil penelitian ini memperlihatkan bahwa perilaku pelat beton untuk parameter lendutan maksimum relatif mengalami penurunan. Lebih jauh untuk parameter beban diperoleh hasil untuk tanah dasar variasi II, III dan IV berturut-turut sebesar $73,47 \mathrm{kN}, 83,25 \mathrm{kN}$, dan 93,50 kN terhadap variasi I sebesar 42,23 kN. Peningkatan beban tersebut sangat signifikan dalam kisaran $174 \%$ sampai dengan $221 \%$. Dan regangan yang terjadi baik untuk variasi I, II, III dan IV dalam kisaran 0,0032 sampai dengan 0,0034.
\end{abstract}

Kata Kunci:

Perkerasan Kaku, Lendutan, Beban, Regangan, dan CBR

\section{PENDAHULUAN}

Jalan Tol Purbaleunyi merupakan ruas jalan yang diharapkan selalu dapat memberikan kinerja fungsional dan struktural yang memenuhi Standar Pelayanan Minimun (SPM) jalan tol. Namun demikian, setiap tahun ruas jalan ini dilakukannya penggantian pelat beton secara penuh/ Full Depth Repair. Seperti yang terjadi pada Km $78+200$ ruas jalan tersebut terjadi kerusakan struktur perkerasan kaku berupa retak-retak yang meluas. Kerusakan struktur perkerasan kaku tersebut dapat disebabkan oleh beberapa faktor diantaranya faktor beban kendaraan yang berlebih, tanah dasar menerima beban yang melebihi daya dukungnya, masuknya air kedalam tanah dasar sehingga menurunkan daya dukungnya, serta adanya jenis kerusakan retak. Jenis kerusakan struktur perkerasan kaku tersebut seperti diperlihatkan pada Gambar 1 dan Gambar 2. Untuk mengurangi kembang susut yang cukup tinggi pada tanah dasar dapat dilakukan dengan melakukan stabilisasi tanah dasar dengan mencampur bahan tambah yang sesuai dengan tekstur dan sifat - sifat fisik tanah tersebut.

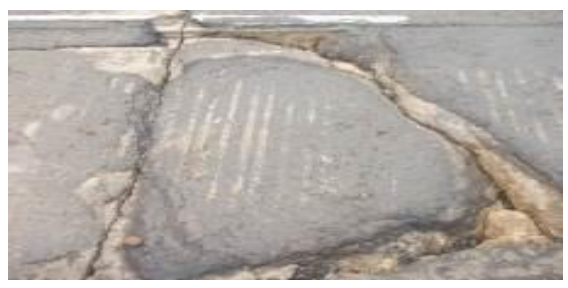

Gambar 1. Retak Acak di Sudut Segmen Perkerasan Kaku

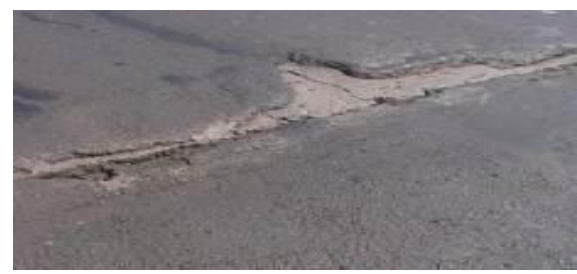

Gambar 2. Kerukan Perkerasan Kaku di Bagian Tengah

Berdasarkan permasalahan yang dijelaskan diatas, maka penelitian ini fokus untuk mempelajari perilaku struktur perkerasan kaku diatas berbagai variasi tanah dasar yang sudah mengalami stabilisasi, termasuk tanah dasar eksisting. Perilaku struktur perkerasan kaku diatas tanah dasar tersebut diperlihatkan oleh kinerja perkerasan seperti parameter penurunan/ lendutan pelat beton dan juga regangan pada saat pelat beton tersebut menerima beban statik monothonic atau Quasi static 


\section{TINJAUAN PUSTAKA}

\subsection{Struktur Perkerasan Kaku}

Struktur perkerasan adalah suatu konstruksi yang terletak di atas lapisan tanah dasar/ subgrade, yang terdiri dari lapisan pondasi (sub base course) dan pelat beton (concrete slab). Susunan lapisan perkerasan kaku dapat dilihat pada Gambar 3.

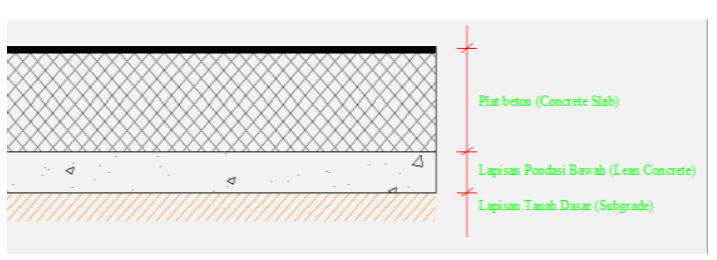

Gambar 3. Susunan lapisan perkerasan kaku.

\subsection{Analisis Struktur Perkerasan kaku}

Modulus of Rupture $\left(M_{R}\right)$ Pendekatan hubungan antara modulus lentur dan kekuatan beton seperti pada Persamaan berikut:

$$
M_{r}=K \sqrt{f c^{\prime}}
$$

Dimana:

$\mathrm{M}_{\mathrm{r}} \quad$ : Modulus lentur (MPa)

K : Konstanta 0,7 untuk agregat tidak dipecah dan 0,75 untuk agregat pecah.

fc' : Kuat tekan beton (MPa)

Pada SNI 03-2847-2002 ditetapkan bahwa lendutan seketika dihitung dengan nilai momen inersia efektif (Ie) berdasar persamaan berikut:

$$
I e=\left(\frac{M_{c r}}{M a}\right) I g+\left\{\left(1-\frac{M_{c r}}{M_{a}}\right)^{3}\right\} I_{c r}
$$

Dengan:

Ie : Momen inersia efektif

Ig : Momen inersia penampang utuh terhadap sumbu berat penampang

Icr : Momen inersia penampang retak trans-formasi

Ma: Momen maksimum pada saat lendutan maksimum dihitung

Mcr: Momen pada saat timbul retak per-tama kali

Nilai Inersia penampang yang diambil adalah inersia penampang pelat beton (I). Nilai inersia untuk penampang sebelum mengalami retak dapat dihitung dengan rumus berikut:

$\mathrm{I}_{\mathrm{cr}} \quad=\frac{1}{3} b y^{3}\left(\mathrm{~m}^{4}\right)$

\subsection{Lendutan Akibat Beban Tengah Dengan Dimensi Pelat Terbatas}

Fleksibilitas balok $(\lambda)$, sebagaimana yang dirumuskan oleh Hetenyi (1974):

$\lambda=\sqrt{\frac{K B}{4 E I}}$

Dengan :

$\lambda$ : Fleksibelitas balok di atas tanah $\left(\mathrm{m}^{-1}\right)$

E : Modulus Elastis balok $(\mathrm{kN} / \mathrm{m} 2)$

$\mathrm{K}$ : Modulus reaksi tanah dasar $(\mathrm{kN} / \mathrm{m} 2)$

I : Momen Inersia Balok $\left(\mathrm{m}^{4}\right)$

Untuk menghitung besaran lendutan struktur perkerasan kaku di atas tanah yang elastis dengan panjang terbatas, yang dibebani beban terpusat pada tengah pelat digunakan Persamaan dari teori balok pada fondasi elastik (Hetenyi, 1974):
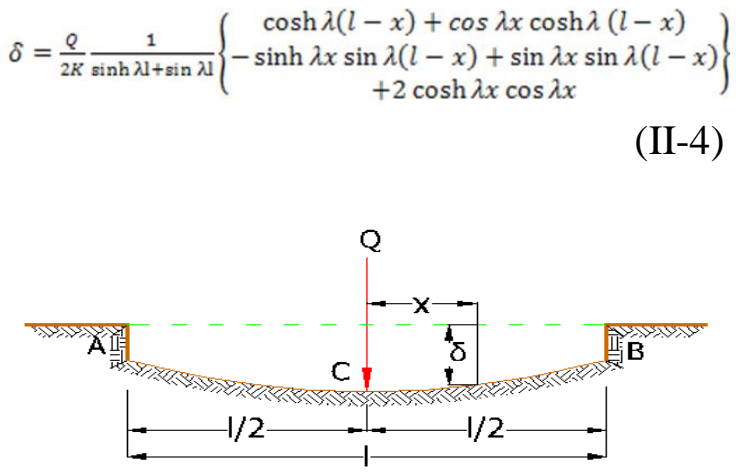

Gambar 4. Balok Terhingga Yang Dibebani Beban Titik Pada Tengah Bentang (Hetenyi, 1974)

\subsection{Tegangan Lentur Akibat Beban Roda}

Tegangan pada permukaan bawah pelat beton dapat dihitung dengan menggunakan rumus berikut (Mathew \& Rao, 2007): seperti terlihat pada Gambar 5.

$\sigma_{b}=\frac{0,316 P}{h^{2}}\left[4 \log _{10}\left(\frac{l}{b}\right)+1,069\right] \ldots \ldots$

Dimana :

$\sigma_{\mathrm{b}}$ :Tegangan tekan pada bagian tarik permukaan bawah pelat akibat beban sumbu kendaraan yang bekerja pada tengah pelat $(\mathrm{kN})$

$\mathrm{P}$ : Beban sumbu ( $\mathrm{kN})$

$\mathrm{h}$ : tebal plat beton $(\mathrm{cm})$

b : radius ekivalen $(\mathrm{cm})$ 


$$
b=\sqrt{1,6 a^{2}+h^{2}}-0,675 h
$$

jika a $<1,724 \mathrm{~h}$

$b=a$

jika a $>1,724 \mathrm{~h}$

Ketika beban diberikan, maka luasan area pelat menahan momen akibat lentur. Westergaard memberikan hubungan radius ekivalen pada bagian bawah pelat.

$l=$ kekakuan relative tanah dasar

Untuk menentukan karakteristik kekakuan relatif lapisan tanah dasar, dapat digunakan rumus berikut ini:

$l=\sqrt[4]{\frac{E h^{3}}{12 K\left(1-\mu^{2}\right)}}$.

Dimana:

E : Modulus elastis pelat beton

$\mu \quad$ : Poison ratio pelat beton, nilai poison diambil $(0,15)$

$\mathrm{K}$ : Modulus reaksi tanah dasar

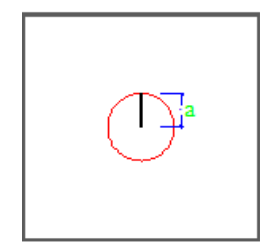

Gambar 5. Pembebanan pada tengah pelat (centre) Sumber: Mathew dkk. (2007)

Besaran tegangan lentur dibatasi dengan tegangan lentur atau biasa disebut modulus lentur. Distribusi tegangan tarik pada permukaan bagian bawah dan bagian atas pelat beton dapat dilihat pada

\section{Gambar 6.}

Secara umum untuk tegangan lentur pada permukaan atas pelat sejauh y dari garis netral dapat digunakan dengan rumus berikut:

$$
\sigma_{l t}=\frac{M \cdot y}{n \cdot I_{e q}}
$$

\section{Dengan:}

$\sigma_{\text {lt }} \quad$ : tegangan akibat lentur

M : momen luar

y $\quad$ : jarak tegangan yang ditinjau ke garis netral ke serat atas pelat beton

I : momen inersia

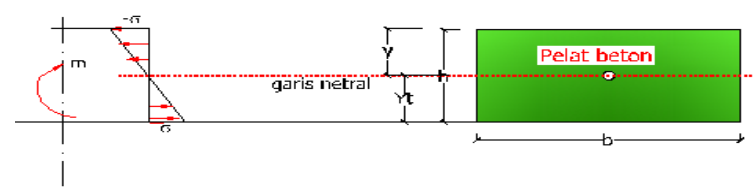

Gambar 6. Distribusi Tegangan Akibat Lentur

\section{METODOLOGI}

Metodologi yang digunakan pada penelitian ini diuraikan seperti pada.

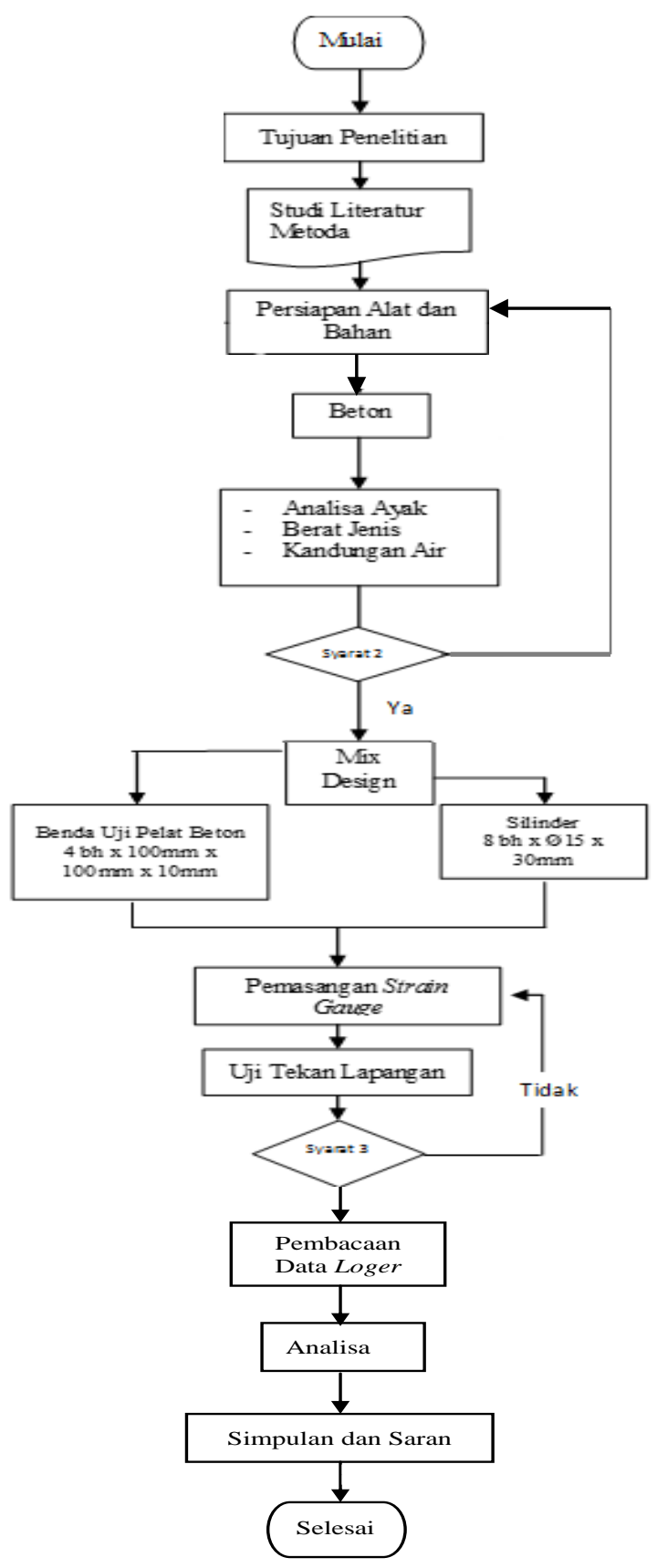

Gambar 7. Bagan Alir Pelaksanaan Penelitian 


\section{HASIL DAN PEMBAHASAN}

\subsection{Pengujian Laboratorium Pengujian Beton}

Di atas tanah dasar diletakkan pelat beton sebagai ilustrasi struktur perkerasan kaku, dengan ukuran, panjang $1.000 \mathrm{~mm} \times$ lebar $1.000 \mathrm{~mm}$ x tebal $100 \mathrm{~mm}$ sebanyak 4 (empat) buah. Pengujian yang dilakukan terhadap beton adalah sebagai berikut

Pengujian Karakteristik Material Pelat Beton, hasil pengujian karakteristik material beton didapat data seperti yang tersaji pada Tabel 1 .

Tabel 1. Hasil Pengujian Bahan

\begin{tabular}{|c|c|c|c|}
\hline $\begin{array}{c}\text { JENIS } \\
\text { PENGUJIAN }\end{array}$ & PASIR & KERIKIL & SEMEN \\
\hline Berat jenis & 2,35 & 2,53 & 2,98 \\
\hline Kadar air & $6,16 \%$ & $1,46 \%$ & - \\
\hline Kadar lumpur & $5,80 \%$ & $1,41 \%$ & - \\
\hline Berat isi & $1,15 \mathrm{gr} / 1$ & $1,15 \mathrm{gr} / 1$ & - \\
\hline Analisa ayakan & 2,70 & 7,11 & - \\
\hline Kadar air lapangan & $8,47 \%$ & $3,30 \%$ & - \\
\hline Penyerapan air & $6,89 \%$ & $2,74 \%$ & - \\
\hline
\end{tabular}

Komposisi Campuran Pelat Beton (Mix Design), merancang beton dapat dilakukan dengan metoda ACI-211-4R-93. Untuk benda uji dengan metode ini digunakan benda uji dengan bentuk silinder. Nilai slump beton segar pada campuran ini adalah $\pm 11 \mathrm{~cm}$. (SNI 03-1973-1990), sedangkan komposisi campu-ran beton untuk $1 \mathrm{~m}^{3}$ lebih rinci dapat dilihat pada Tabel 2.

Tabel 2 Komposisi Campuran Beton

\begin{tabular}{|l|c|c|}
\hline \multirow{2}{*}{\multicolumn{1}{|c|}{ BAHAN }} & \multicolumn{2}{c|}{ KOMPOSISI 1 M ${ }^{3}$ BETON } \\
\cline { 2 - 3 } & BERAT (Kg) & PERBANDINGAN BERAT \\
\hline \hline Semen & 342 & 1 \\
\hline Agregat Halus & 729 & 2,11 \\
\hline Agregat Kasar & 1.088 & 3,17 \\
\hline
\end{tabular}

Pengujian Kuat Tekan Beton adalah muatan tekan maksimum yang dapat dipikul oleh beton persatuan luas dengan menggunakan mesin tekan. Pada metode ini untuk menentukan kuat tekan yang direncanakan (f'cr) dapat dilakukan berdasarkan pengalaman dilapangan dengan rumus:

$$
\mathbf{f}^{\prime} \mathbf{c r}=\mathrm{f}^{\prime} \mathrm{c}+1,34 \mathrm{Sd}
$$

Dimana :

f'cr : Kuat tekan rata-rata yang disyaratkan (MPa)

f'c : Kuat tekan rata-rata yang ditargetkan (MPa)

Sd : Standar deviasi

Kuat tekan beton dilakukan pada benda uji dengan ukuran diameter ( $\varnothing) 150 \mathrm{~mm}$ x Tinggi 300 $\mathrm{mm}$, sejumlah 8 (delapan) buah, sesuai rujukan metode British Standart 1988.

Hasil dari pengujian kuat tekan silinder beton sebanyak 8 (delapan) buah sampel dapat ditabelkan sebagai berikut.Tabel 3 .
Tabel 3 Hasil Uji Tekan Silinder Beton

\begin{tabular}{|c|c|c|c|c|c|}
\hline \multirow[b]{2}{*}{$\begin{array}{c}\text { KODE } \\
\text { SAMPEL }\end{array}$} & \multicolumn{2}{|c|}{ DIMENSI } & \multirow[b]{2}{*}{$\begin{array}{c}\text { BERAT } \\
(\mathrm{Kg})\end{array}$} & \multirow{2}{*}{$\begin{array}{c}\text { NILAI KUAT } \\
\text { TEKAN } \\
(\mathrm{Kg} / \mathrm{cm} 2)\end{array}$} & \multirow{2}{*}{$\begin{array}{l}\text { NILAI KUAT } \\
\text { TEKAN } \\
(\mathrm{MPa})\end{array}$} \\
\hline & $\begin{array}{c}\varnothing \\
\mathrm{mm}\end{array}$ & $\begin{array}{l}\text { TINGGI } \\
\text { mm }\end{array}$ & & & \\
\hline S1 & 150 & 300 & 12,10 & 204,31 & 20,03 \\
\hline S2 & 150 & 300 & 12,09 & 171,80 & 1.684 \\
\hline S3 & 150 & 300 & 11,88 & 184,50 & 1.809 \\
\hline S4 & 150 & 300 & 11,97 & 237,60 & 23,30 \\
\hline S5 & 150 & 300 & 12,20 & 268,04 & 26,28 \\
\hline S6 & 150 & 300 & 12.14 & 237,60 & 23,30 \\
\hline S7 & 150 & 300 & 12,02 & 268,04 & 26,28 \\
\hline S8 & 150 & 300 & 11,98 & 272,91 & 26,76 \\
\hline \multicolumn{4}{|c|}{ Rata-rata kuat tekan ( $\left.\mathrm{f}^{\circ} \mathrm{cr}\right)$} & 230,60 & 23,320 \\
\hline \multicolumn{4}{|c|}{ Standar Deviasi } & 16,36 & 16,360 \\
\hline \multicolumn{4}{|c|}{ Konstanta Statistik } & 1,34 & 1,34 \\
\hline \multicolumn{4}{|c|}{ Kuat Tekan Karakteristik Umur 28 Hari } & 252,52 & 25,68 \\
\hline
\end{tabular}

Proses perhitungan hasil uji tekan silinder dengan menggunakan rumus sebagai berikut:

$$
\begin{aligned}
\mathbf{f} ' \mathbf{c r} & =\mathrm{fc}+1,34 * 16,36(\mathbf{A C I}-211.4 R-93) \\
& =230,60+1,34 * 16,36 \\
& =\mathbf{2 5 2 , 5 2} \mathrm{Kg} / \mathrm{cm}^{2}
\end{aligned}
$$

Setelah melalui perhitungan standar deviasi dan konstanta statistic, maka didapat rata-rata kuat tekan beton sebesar $252,52 \mathrm{Kg} / \mathrm{cm}^{2}$, dibulatkan menjadi $25 \mathrm{MPa}$.

\subsection{Pengendalian Mutu Beton}

Pengendalian mutu beton dapat dilaku-kan dengan mengecek mutu beton pada saat beton segar, beton dalam masa perawatan dan saat beton keras, sesuai rujukan SNI-03-2493-1991.

Pengujian Beton Segar yang dilakukan diantaranya pengujian kelecakan/slump test, pengujian slump test campuran beton pada penelitian ini mencapai $\pm 110 \mathrm{~mm}$, sesuai dengan standart SNI 03-1973-1990. Dilakukan pula pengecoran pelat beton sebagai ilustrasi dari struktur perkerasan kaku. Ukuran pelat beton adalah panjang $1.000 \mathrm{~mm}$ x lebar $1.000 \mathrm{~mm}$ x tebal $100 \mathrm{~mm}$, sejumlah 4 (empat) buah.

Perawatan Beton dilakukan dengan menutup permukaan beton dengan karung goni basah. Setelah umur beton mencapai 7 (tujuh) hari cetakan disisi kiri dan kanan dilepas, sedangkan karung goni dikondisikan selalu basah. Perawatan beton dilakukan sampai beton mencapai umur 28 (dua puluh delapan) hari. Perawatan beton penting dilakukan sebagaimana yang disyaratkan SNI-032493-1991.

Pemasangan Sensor/ Strain Gauges, Maksud dari pemasangan strain gauges tersebut agar dapat menditeksi regangan yang terjadi serta dapat berupa besar tekanan, regangan, lendutan dan retak awal. Pengujian Kepadatan Pelat Beton dilakukan dengan menggunakan pengujian beton non distruktif yaitu 
menggunakan alat pundit. Proses uji kepadatan pelat beton dengan menggunakan alat pundit, yaitu mengukur kecepatan rambat gelombang yang ditimbulkan alat pundit melalui dua buah transducer dengan jarak tertentu.

Hasil pengujian kepadatan pelat beton dapat dilihat pada Tabel 4

Uji kepadatan : Pelat Beton

Lokasi : Laboratorium Beton

Kegiatan : Uji Kepadatan Beton dengan Alat Pundit (Proceq)

Tanggal Inspeksi : 5 September 2016

Tabel 4 Uji Kepadatan Pelat Beton

\begin{tabular}{|c|c|c|c|c|c|c|c|}
\hline VARIASI & $\begin{array}{c}\text { NOMOR } \\
\text { LOKASI } \\
\text { UJI }\end{array}$ & LOKASI UJI & ID & $\begin{array}{c}\mathbf{L} \\
\mathbf{C m}\end{array}$ & $\begin{array}{c}\mathbf{t}_{1} \\
\boldsymbol{\mu} \mathbf{s}\end{array}$ & $\begin{array}{c}\mathbf{t}_{2} \\
\boldsymbol{\mu} \mathbf{s}\end{array}$ & $\begin{array}{c}\mathbf{V} \\
\mathbf{m} / \mathbf{s}\end{array}$ \\
\hline \multirow{3}{*}{ I } & 1 & $\begin{array}{l}\text { S Kr Atas }_{1} \\
\text { S KrTengah } 1 \\
\text { S Kr Bawah } 1\end{array}$ & 637 & 15 & 41,9 & 89,0 & 2.123 \\
\hline & 2 & $\begin{array}{l}\text { Tengah } 1 \\
\text { Tengah } 2 \\
\text { Tengah } 3\end{array}$ & 638 & 15 & 49,1 & 77,4 & 3.534 \\
\hline & 3 & $\begin{array}{l}\text { S Kn Atas }_{3} \\
\text { S Kn Tengah } 3_{3} \\
\text { S Kn bBawah }_{3}\end{array}$ & 639 & 15 & 49,2 & $90, .5$ & 2.421 \\
\hline \multirow{3}{*}{ II } & 4 & $\begin{array}{l}\text { S Kr Atas } 4 \\
\text { S Kr Tengah }_{4} \\
\text { S Kr Bawah }_{4}\end{array}$ & 640 & 15 & 39,8 & 73,9 & 2.933 \\
\hline & 5 & $\begin{array}{l}\text { Tengah }_{1} \\
\text { Tengah } 2 \\
\text { Tengah } 3\end{array}$ & 641 & 15 & 24,4 & 63,6 & 2.591 \\
\hline & 6 & $\begin{array}{l}\text { S Kn Atas } 6 \\
\text { S Kn Tengah } 6 \\
\text { S Kn Bawah } 6\end{array}$ & 642 & 15 & 41,7 & 74,8 & 3.021 \\
\hline \multirow{3}{*}{ III } & 7 & $\begin{array}{l}\text { S Kr Atas } 7 \\
\text { S Kr Tengah } 7 \\
\text { S Kr Bawah } 7\end{array}$ & 643 & 15 & 34,1 & 55,8 & 4.608 \\
\hline & 8 & $\begin{array}{l}\text { Tengah }_{1} \\
\text { Tengah } 2 \\
\text { Tengah }_{3}\end{array}$ & 644 & 15 & 24,2 & $63, .7$ & 2.532 \\
\hline & 9 & $\begin{array}{l}\text { S Kn Atas } 9 \\
\text { S Kn Tengah } 9 \\
\text { S Kn Bawah } 9\end{array}$ & 645 & 15 & 31,6 & 68,4 & 2.717 \\
\hline \multirow{3}{*}{ IV } & 10 & $\begin{array}{l}\text { S Kr Atas } 10 \\
\text { S Kr Tengah }_{10} \\
\text { S Kr Bawah }_{10}\end{array}$ & 646 & 15 & 37,8 & 77,3 & 2.532 \\
\hline & 11 & $\begin{array}{l}\text { Tengah } 1 \\
\text { Tengah } 2 \\
\text { Tengah } 3\end{array}$ & 647 & 15 & $35, .2$ & 67,6 & 3.086 \\
\hline & 12 & $\begin{array}{l}\text { S Kn Atas } 12 \\
\text { S Kn Tengah } 12 \\
\text { S Kn Bawah } 12\end{array}$ & 648 & 15 & $36, .0$ & 70,4 & 2.907 \\
\hline
\end{tabular}

Keterangan Tabel $\mathbf{4}$ adalah sebagai berikut:

ID : No urut pengujian yang tertera dialat

uji.

L : Jarak Transducer ke Transducer lain

$\mathrm{t}_{1} \quad$ :Tranducer 1

$\mathrm{t}_{2} \quad$ :Transducer 2

$\mathrm{V}$ : Kecepatan Rambat $(\mu / \mathrm{s})$ 


\subsection{Pengujian Lapangan}

\subsubsection{Uji Tekan Pelat Beton}

Uji tekan di lapangan dilakukan dengan media strain gauges, alat Linier Variable Deferensial Tranducer (LVDT), Load cells dan satu set data logger. Tujuan alat tersebut untuk mendapatkan data regangan, tegangan dan lendutan dititik-titik tertentu saat dilakukan uji tekan.

\subsection{Pembahasan Hasil Pengujian Lapangan}

Setelah dilakukan analisis terhadap hasil pengujian lapangan baik terhadap tanah dasar dan pelat beton, maka diperoleh kesimpulan bahwa dengan meningkatnya nilai CBR tanah dasar akan meningkatkan daya dukung tanah yang dapat diberikan kepada pelat beton. Sesuai dengan rujukan SNI 03-1732-1989 dan SKBI 2.3.26.1987 bahwa Nilai CBR erat hubungannya dengan daya dukung tanah. Hasil pengujian dapat dilihat pada Tabel 5.

Tabel 5. Hasil Pengujian Tanah Dasar dan Pelat Beton Lapangan

\begin{tabular}{c|c|c|c|c|c}
\hline VARIASI & $\begin{array}{c}\text { KEPADATAN } \\
\text { SAND } \\
\text { CONE } \\
\%\end{array}$ & $\begin{array}{c}\text { CBR } \\
\text { LAPANGAN } \\
\%\end{array}$ & $\begin{array}{c}\text { BEBAN } \\
(\mathrm{kN})\end{array}$ & $\begin{array}{c}\text { LENDUTAN } \\
\text { mm }\end{array}$ & $\begin{array}{c}\text { REGANGAN } \\
(\varepsilon)\end{array}$ \\
\hline \hline I & 70,43 & 4.61 & 42,23 & 9,2 & 0,0032 \\
\hline II & 85,03 & 24,57 & 76,73 & 8,5 & 0,0034 \\
\hline III & 86,32 & 31,01 & 84,37 & 5,2 & 0,0032 \\
\hline IV & 93,35 & 34,15 & 94,05 & 4,4 & 0,0032 \\
\hline
\end{tabular}

Dari Tabel 5. dapat dijelaskan bahwa Pengaruh perilaku pada pelat beton diantaranya beban yang dipikul menunjukan peningkatan sejalan dengan meningkatnya nilai CBR, begitu pula tingginya prosentase nilai CBR dapat memperkecil nilai lendutan yang terjadi pada pelat beton.

Tabel 6 Hasil Pengujian Pembebanan Terhadap Penurunan dan Lendutan Pelat Beton

\begin{tabular}{|c|c|c|c|c|c|c|c|c|c|}
\hline \multirow{3}{*}{ Variasi } & \multicolumn{6}{|c|}{ Tahap Penurunan } & \multirow{2}{*}{\multicolumn{3}{|c|}{$\begin{array}{c}\text { Tahap Lendutan } \\
\text { Posisi Tengah }\end{array}$}} \\
\hline & \multicolumn{2}{|c|}{ Posisi Kiri } & \multicolumn{2}{|c|}{ Posisi Kanan } & \multicolumn{2}{|c|}{ Posisi Tengah } & & & \\
\hline & $\begin{array}{l}\text { LVDTI } \\
(\mathrm{mm})\end{array}$ & $\begin{array}{c}\text { Beban } \\
(\mathrm{kN})\end{array}$ & $\begin{array}{l}\text { LVDT3 } \\
(\mathrm{mm})\end{array}$ & $\begin{array}{c}\text { Beban } \\
(\mathrm{kN})\end{array}$ & $\begin{array}{c}\text { LVDI2 } \\
(\mathrm{mm})\end{array}$ & $\begin{array}{c}\text { Beban } \\
(\mathrm{klN})\end{array}$ & $\underset{(\mathrm{mm})}{\mathrm{LVDT2}}$ & $\begin{array}{l}\text { Beban } \\
(\mathrm{kll})\end{array}$ & $\begin{array}{c}\text { Lendutan } \\
\text { relatif } \\
(\mathrm{mm})\end{array}$ \\
\hline I & 2,84 & 42,13 & 2,90 & 42,23 & 2,86 & 17,66 & 9,13 & 42,23 & 6,26 \\
\hline II & 2,52 & 76,73 & 2,95 & 76,73 & 0,97 & 12,50 & 8,41 & 73,47 & 5,66 \\
\hline III & 1,45 & 83,36 & 2,58 & 80,98 & 2,48 & 27,31 & 5,21 & 83,25 & 3,19 \\
\hline IV & 1,23 & 89,71 & 4,52 & 93,03 & 1,68 & 31,42 & 4,52 & 93,50 & 2,57 \\
\hline
\end{tabular}

Tabel 6 memperlihatkan perilaku pelat beton diatas berbagai variasi kondisi tanah dasar pada saat diberikan beban diatasnya. Perilaku pelat beton tersebut dinyatakan dalam parameter penurunan dan lendutan.
Walaupun tanah dasar tersebut sudah mendapatkan pemadatan, namun demikian masih mengalami pemadatan setelah menerima beban yang diteruskan melalui pelat beton. Dalam kenyataan dilapangan untuk mengurangi adanya penurunan pelat beton terutama pada bagian sisi pelat beton, maka digunakan dowel dan tie bar, sehingga beban yang diterima oleh tanah dasar akan semakin kecil.

Pada saat pelat beton tidak lagi mengalami penurunan, maka selanjutnya perilaku pelat beton adalah mengalami lendutan. Landutan terbesar terjadi pada bagian tengah pelat beton.

Lendutan yang terjadi pada pelat beton yang melebihi kapasitasnya dapat menyebabkan pelat beton tersebut mengalami retak permukaan dan retak menerus sampai pada bagian bawah pelat beton. Pada struktur perkerasan kaku, jenis kerusakan retak ditangani dengan mengisi celah retak tersebut dengan sealant atau dengan melakukan partial depth repair atau full depth repair. .

Disisi lain dengan meningkatnya daya dukung tanah dasar yang dapat diberikan kepada pelat beton, maka besarnya beban yang dapat diterima oleh pelat beton semakin besar, sampai pelat beton mengalami keruntuhan. Sebagai contoh untuk pelat beton diatas tanah dasar variasi I dan diatas tanah dasar variasi IV mengalami peningkatan yang signifikan dari $42,23 \mathrm{kN}$ menjadi $93,50 \mathrm{kN}$, lebih dari $200 \%$.

Pada kenyataan dilapangan, suatu struktur perkerasan kaku akan mengalami pembebanan dari kendaraan yang melewatinya secara terus menurus atau berulang-ulang selama umur rencana, dikenal dengan istilah Cummulative Equivalent Standard Axle load (CESA). Dalam penelitian ini telah memperlihatkan bahwa dengan semakin besarnya daya dukung yang dapat diberikan oleh tanah dasar, maka beban yang dapat diterima oleh pelat beton semakin besar.

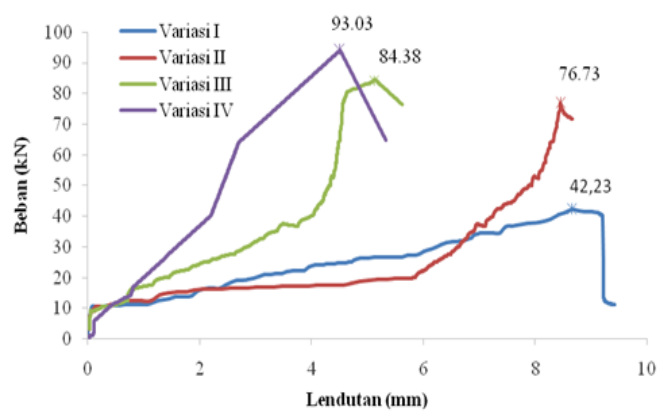

Gambar 8. Lendutan Pelat Beton pada Tanah Dasar Variasi I, II, III dan IV 
Gambar 8 memperlihatkan bahwa besarannya lendutan yang terjadi pada pelat beton sangat dipengaruhi oleh kondisi tanah dasar dengan meningkatnya persentase campuran bahan tambah kerikil dan pasir, maka terjadi peningkatan nilai CBR tanah dasar. Hal tersebut sejalan dengan yang dikemukakan oleh Ahmed Salim AL Riyami(undated) bahwa penggunaan tanah dasar pasir halus baik dalam mengurangi lendutan pelat beton pada saat menerima beban.

Besaran lendutan pelat beton sendiri secara teoritis dapat dihitung (hetenyi, 1979). Adapun formula yang digunakan dalam pehitungan lendutan pada pelat beton sebagai berikut (Persamaan II-3):

$$
\lambda_{n}=\sqrt{\frac{k_{C n} B}{4 E I}}\left(\mathrm{~m}^{-1}\right)
$$

Sehingga diperoleh nilai fleksibilitas pelat $(\lambda)$

Variasi I $\lambda_{1}=\sqrt[4]{\frac{k_{C 1} B}{4 E I}}\left(\mathrm{~m}^{-1}\right)$

$$
=\sqrt[4]{\frac{930,2 \times 1}{4 \times 23593_{\imath} 81 \times 0,83 \times 10^{-4}}}=0,58 \mathrm{~m}
$$

Variasi II $\lambda_{2}=\sqrt[4]{\frac{k_{C 2} B}{4 E I}}\left(\mathrm{~m}^{-1}\right)$

$$
=\sqrt[4]{\frac{1929 \times 1}{4 \times 23593_{\imath} 81 \times 0,83 \times 10^{-4}}}=0,703 \mathrm{~m}
$$

Dimana:

$\lambda_{1}$ adalah fleksibilitas pelat beton variasi $1 ; \lambda_{2}$ adalah fleksibilitas pelat beton variasi $2 ; \lambda_{3}$ adalah fleksibilitas untuk pelat beton variasi 3 dan $\lambda_{4}$ adalah fleksibilitas untuk pelat beton variasi 4 .

Besaran lendutan dengan panjang balok terhingga dapat dihitung dengan Persamaan (II-4), sebagaimana dapat dilihat pada

Perhitungan secara empiris dengan besaran beban yang diberikan adalah pada saat pelat beton mengalami mengalami keruntuhan. Sebagai contoh perhitungan pada variasi 1 dengan beban saat mengalami keruntuhan sebesar 42,23 kN. Modulus reaksi tanah dasar $\left(\mathrm{k}_{\mathrm{c} 1}\right) 930,2 \mathrm{kN} / \mathrm{m}^{3}$, lebar pelat beton (l) $1,0 \mathrm{~m}^{1}$, fleksibilitas pelat $\left(\lambda_{1}\right) 0,58 \mathrm{~m}$, dan
Dimana :

$\mathrm{k}_{\mathrm{c}}=$ Modulus reaksi tanah $\left(\mathrm{kN} / \mathrm{m}^{3}\right)$, dari perhitungan diperoleh nilai $\mathrm{kc}_{1} 930,2 \mathrm{kN} / \mathrm{m}^{3}, \mathrm{kc}_{2} 1929 \mathrm{kN} / \mathrm{m}^{3}, \mathrm{kc}_{3}$ $2239 \mathrm{kN} / \mathrm{m}^{3}$, dan $\mathrm{kc}_{4} 2549 \mathrm{kN} / \mathrm{m}^{3}$

$\mathrm{B}=$ lebar pelat beton,yaitu $1,0 \mathrm{~m}$;

$$
\begin{aligned}
\mathrm{E} & =4700 \sqrt{f c^{\prime}}\left(\mathrm{kN} / \mathrm{m}^{2}\right) \\
& =4700 \sqrt{25,2}=23593,81 \mathrm{kN} / \mathrm{m}^{2}
\end{aligned}
$$

Inersia pelat beton dihitung dengan persamaan (II-2), berikut contoh perhitungannya.

$$
\begin{aligned}
\mathrm{I}=\text { momen inersia } & =\frac{1}{12} b x h^{3}\left(\mathrm{~m}^{4}\right) . \\
& =\frac{1}{12} 1 \times 0,1^{3}=0,83 \times 10^{-4} \mathrm{~m}^{4}
\end{aligned}
$$

$$
\begin{aligned}
\text { Variasi III } \lambda_{3} & =\sqrt[4]{\frac{k_{C g} B}{4 E I}}\left(\mathrm{~m}^{-1}\right) \\
& =\sqrt[4]{\frac{2239 \times 1}{4 \times 23593,81 \times 0,83 \times 10^{-4}}}=0,73 \mathrm{~m} \\
\text { Variasi IV } \lambda_{4} & =\sqrt[4]{\frac{k_{C g} B}{4 E I}}\left(\mathrm{~m}^{-1}\right. \\
& =\sqrt[4]{\frac{2549 \times 1}{4 \times 23593,81 \times 0,83 \times 10^{-4}}}=0,75
\end{aligned}
$$$$
\delta=\frac{Q}{2 K} \frac{1}{\sinh \lambda \mathrm{l}+\sin \lambda \mathrm{l}}\left\{\begin{array}{c}
\cosh \lambda(l-x)+\cos \lambda x \cosh \lambda(l-x) \\
-\sinh \lambda x \sin \lambda(l-x)+\sin \lambda x \sin \lambda(l-x) \\
+2 \cosh \lambda x \cos \lambda x
\end{array}\right\}
$$

Dimana:

$$
\begin{array}{ll}
\delta & =\text { besaran lendutan }(\mathrm{m}) \\
\mathrm{Q} & =\text { beban titik }(\mathrm{kN}) \\
1 & =\text { lebar pelat beton }(\mathrm{m}) \\
\mathrm{x} & =\text { jarak dari titik beban ke pinggir } \\
\text { pelat beton }
\end{array}
$$

jarak titik beban ke tepi pelat (x) 0,5 m, seperti berikut ini:

$$
\delta=\frac{Q}{2 K} \frac{1}{\sinh \lambda l+\sin \lambda l}\left\{\begin{array}{c}
\cosh \lambda(l-x)+\cos \lambda x \cosh \lambda(l-x) \\
-\sinh \lambda x \sin \lambda(l-x)+\sin \lambda x \sin \lambda(l-x) \\
+2 \cosh \lambda x \cos \lambda x
\end{array}\right\}
$$


$\delta_{1}=$

$\frac{42,23}{2 \times 930,2} \frac{1}{\sinh 0,58 \times 1+\sin 0,58 \times 1} \times\left\{\begin{array}{c}\cosh 0,58(1-0,5)+\cos 0,58 \times 0,5 \cosh 0,58(1-0,5) \\ -\sinh 0,58 \times 0,5 \times \sin 0,58(1-0,5)+\sin 0,58 \times 0,5 \sin 0,58(1-0,5) \\ +2 \cosh 0,58 \times 0,5 \cos 0,58 \times 0,5\end{array}\right\}$
$=7,8 \mathrm{~mm}$

Selanjutnya dengan perhitungan yang sama, nilai lendutan semua variasi disajikan pada Tabel 7 .

Tabel 7. Lendutan Lapangan dan Lendutan Teoritis

\begin{tabular}{|c|c|c|c|c|c|c|}
\hline VARIASI & $\begin{array}{c}\text { KEPADATAN } \\
\text { SAND } \\
\text { CONE } \\
\% \\
\end{array}$ & $\begin{array}{c}\text { CBR } \\
\text { LAPANG.AN } \\
\%\end{array}$ & $\frac{\text { BEBAN }}{(\mathrm{kV})}$ & $\begin{array}{c}\text { LENDUTAN } \\
\text { UJ } \\
\text { LAPANGAN } \\
(\mathrm{mm}) \\
\end{array}$ & $\begin{array}{c}\text { LENDUTAN } \\
\text { HASII } \\
\text { TEORIIS } \\
(\mathrm{mm}) \\
\end{array}$ & $\begin{array}{c}\text { SELISTH } \\
(\%)\end{array}$ \\
\hline I & 42,23 & 4.61 & 42,23 & 6,26 & 7,8 & 24,60 \\
\hline II & 85,03 & 24,57 & 76,73 & 5,67 & 5,9 & 5,29 \\
\hline III & 86,32 & 31,01 & 84,37 & 3,19 & 3,24 & 1,56 \\
\hline IV & 93,35 & 34,15 & 94,05 & 2,56 & 2,85 & 11,33 \\
\hline
\end{tabular}

Besaran nilai lendutan hasil teoritis lebih besar dari nilai hasil lendutan hasil uji, dimana selisih antara teoritis dan uji adalah sebesar 24,60\%; $3,87 \%$; $1,25 \%$; dan $16,33 \%$ berturut-turut untuk variasi I sampai dengan variasi IV. Ini menunjukkan secara teoritis dapat digunakan untuk perhitungan lendutan pada perkerasan kaku.

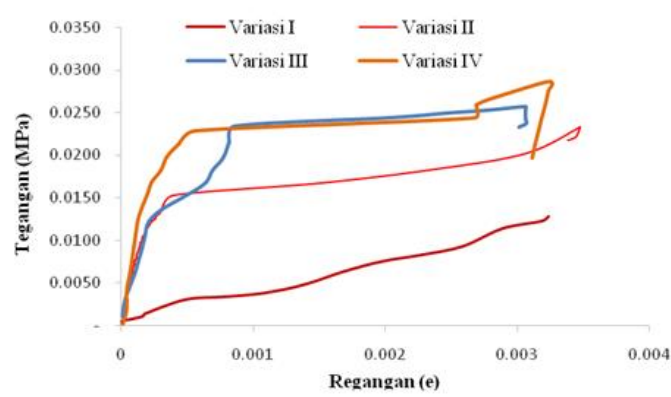

Gambar 9. Regangan dan Tegangan Variasi I sampai dengan Variasi IV

Selanjutnya untuk besaran regangan yang terjadi pada tiap variasi sebagaimana ditunjukkan pada Gambar 9. Untuk variasi I, hasil uji menunjukkan keruntuhan terjadi pada saat regangan mencapai 0,0032, dan nilai tegangan diperoleh dari hasil perhitungan sebesar 0,0130 $\mathrm{MPa}$. Kemudian untuk variasi II terjadi keruntuhan pada saat regangan mencapai 0,0034 dengan nilai tegangan sebesar 0,020 MPa. Selanjutnya untuk variasi III dan variasi IV terjadi keruntuhan berturut-turut pada saat regangan mencapai 0,0032 dan 0,0032 dengan tegangan sebesar 0,026 MPa dan 0,280 MPa. Dapat disimpulkan bahwa meningkatnya nilai CBR pada tanah yang distabilisasi, maka tegangan untuk mencapai keruntuhan semakin besar.

Besaran tegangan yang terjadi diperoleh secara hitungan teoritis, dimana tegangan yang terjadi pada bagian permukaan bawah pelat (Westtergaard, 1926). Sebagai contoh perhitungan tegangan adalah sebagai berikut:

$$
\sigma_{b}=\frac{0,316 P}{h^{2}}\left[4 \log _{10}\left(\frac{l}{b}\right)+1,069\right]
$$

Sebagai contoh perhitungan adalah variasi 1

$$
\begin{aligned}
& \mathrm{E} \quad=\quad 23611,28023(\mathrm{MPa}) \\
& \mathrm{h} \quad=\quad 0,1 \quad(\mathrm{~m}) \\
& \mathrm{k} \quad=\quad 930,2 \quad\left(\mathrm{kN} / \mathrm{m}^{3}\right. \\
& \mu \quad=0,15 \\
& \text { a } \quad=\quad 17,2 \quad\left(\mathrm{~cm}^{2}\right)
\end{aligned}
$$

Dimana :

$l=\sqrt[4]{\frac{E h^{8}}{12 K\left(1-\mu^{2}\right)}}=\sqrt[4]{\frac{23611,28 \times 0,1^{8}}{12 \times 930,2\left(1-0,15^{2}\right)}}=0,215$

$\mathrm{b}=$ radius bidang kontak

$$
\begin{aligned}
& b=\sqrt{1,6 a^{2}+h^{2}}-0,675 h \\
& \text { jika a }<1,724 \mathrm{~h} b=a
\end{aligned}
$$

jika a $>1,724 \mathrm{~h}$

$\mathrm{a}=0,172<1,724 \mathrm{~h}=0,172$, maka $\mathrm{b}=0,175$

$\mathrm{m}$

$b=\sqrt{1,6 \times 17,5^{2}+0,1^{2}}-0,675 \times 0,1$

$$
=0,175 \mathrm{~m}
$$

beban pada variasi 1 dengan beban mencapai keruntuhan sebesar $\mathrm{P}=42,23 \mathrm{kN}$, maka:

$$
\begin{aligned}
\sigma_{b} & =\frac{0,316 P}{h^{2}}\left[4 \log _{10}\left(\frac{l}{b}\right)+1,069\right] \\
\sigma_{b} & =\frac{0,316 \times 42,23}{0,1^{2}}\left[4 \log _{10}\left(\frac{0,215}{0,175}\right)+1,069\right] \\
& =13 \mathrm{kN} \\
& =0,013 \mathrm{Mpa}
\end{aligned}
$$

Selanjutnya dengan hasil perhitungan yang sama, maka diperoleh nilai tegangan pada masing-masing variasi sebagaimana disajikan pada Tabel 8 . 
Tabel 8. Tegangan pada Serat Permukaan Bawah Pelat Akibat Beban Terpusat

\begin{tabular}{|c|c|c|c|c|c|c|}
\hline No & Variasi & $\begin{array}{c}\text { Beban } \\
(\mathrm{kN})\end{array}$ & $\begin{array}{c}\mathrm{k} \\
\left(\mathrm{kN} / \mathrm{m}^{3}\right)\end{array}$ & $l$ & $\begin{array}{c}\text { Tegangan } \\
\text { Hasil } \\
\text { Teoritis } \\
(\mathrm{MPa})\end{array}$ & $\begin{array}{c}\text { Regangan } \\
\begin{array}{c}\text { Hasil Uji } \\
\text { Lapangan } \\
(\varepsilon)\end{array}\end{array}$ \\
\hline 1 & I & 42,23 & 930,2 & 0,215 & 0,0130 & 0,0032 \\
\hline 2 & II & 76,73 & 1929 & 0,179 & 0,0230 & 0,0034 \\
\hline 3 & III & 84,37 & 2239 & 0,173 & 0,0260 & 0,0032 \\
\hline 3 & IV & 94,05 & 2549 & 0,167 & 0,2800 & 0,0032 \\
\hline
\end{tabular}

Stabilisasi tanah dasar dengan bahan tambahan pasir dan kerikil terbukti dari hasil penelitian, diperlihatkan oleh variasi II, III dan IV, dapat menurunkan nilai lendutan dan meningkatkan besarnya beban yang dapat diterima oleh pelat beton. Walaupun besarnya regangan tidak mengalami perubahan yang signifikan.

\section{SIMPULAN}

a. Besarnya beban yang dapat diterima oleh pelat beton, sampai dengan pelat beton mengalami keruntuhan, meningkat sejalan dengan meningkatnya daya dukung tanah dasar variasi II, III dan IV berturut-turut sebesar $73,47 \mathrm{kN}$, $83,25 \mathrm{kN}$ dan $93,50 \mathrm{kN}$ terhadap variasi I sebesar 42,23 kN. Peningkatan beban tersebut sangat signifikan dalam kisaran $174 \%$ sampai dengan $221 \%$.

b. Lendutan maksimum relatif yang terjadi pada pelat beton mengalami penurunan menjadi 5,66 $\mathrm{mm}, 3,19 \mathrm{~mm}$ dan 2,57 $\mathrm{mm}$ berturut-turut untuk tanah dasar variasi II, III dan IV terhadap tanah dasar variasi I sebesar yaitu $6,26 \mathrm{~mm}$.

c. Perbedaan lendutan yang terjadi pada pelat beton hasil dari pengujian lapangan dan hitungan secara teoritis memberikan perbedaan dalam kisaran $1 \%$ sampai dengan $25 \%$. Perbedaan terbesar terjadi pada tanah dasar variasi I dan terkecil terjadi pada tanah dasar variasi IV.

d. Peningkatan beban yang diterima oleh pelat beton tidak memberikan perubahan yang signifikan terhadap besarnya regangan. Regangan yang terjadi pada pelat beton dalam kisaran 0,0032 sampai dengan 0,0034, hal tersebut sesuai dengan yang dijelaskan dalam ACI 318 bahwa regangan maksimum yang terjadi dalam rentang 0,003 sampai dengan 0,005

\section{DAFTAR PUSTAKA}

Ahmed Salim AL Riyami (undated), Experimental Behavior of Model Rigid Pavements Supported on Typical Representative Subgrades of Oman, Civil and Architectural Engineering Department-College of Engineering-Sultan Qaboos University.

Anas Puri, Hary Christady Hardiyatmo, Bambang Suhendro, dan Ahmad Rifai (2015), Perilaku Perkerasan Sistem Pelat Terpaku Pada Tanah Dasar Lempung Lunak. Prosiding Konferensi Nasional Pascasarjana Teknik Sipil (KNPTS) 2015, ISSN 2477-0086.

AASHTO (1978), Standard Specification for Transportation Material and Methods of Sampling and Testing, $12^{\text {th }}$ Ed Washington D.C Part, 1998 pp.

Clark Graves. R, David L Allen (1992), Pavement Deflection Evaluations, Federal Highway administration U.S Departement of Transportation.

Chen, F.H, 1975 Pondation on Expansiv Soil, Developments in Geotechnical Engineering 12,Elsevier Scientific Publishing Company,Amsterdam.

Dachlan A. (2009). Kajian Lapangan Perkerasan Jalan Beton Pracetak di Indonesia, Jurnal Jalan dan Jembatan Vol. 26 N0. 32009.

Darestani M. Y, David P. Thambiratnam and A. Nataatmadja (2006)., Experimental Study On Structural Response of Rigid Pavements Under Moving Truck Load, 22 $2^{\text {nd }}$ ARRB Conference - Research into Practice, Canberra Australia.

Das. Braja, M. (1998). Mekanika Tanah. Erlangga. Jakarta.

Fendi Hary Yanto (2015). Analisis Lendutan Perkerasan Kaku Pada Tanah Lunak Dengan Perkuatan Kolom Soil Cement. Tesis Magister Teknik, Program Pasca Sarjana Universitas Seberat Maret Surakarta.

Hakam Abdul. (2010). Studi Pengaruh Penambahan Tanah Lempung pada Tanah Pasir Pantai Terhadap Kekuatan Geser Tanah.

Hendarsin Shirley, L. (2008), Perencanaan Teknik Jalan Raya, Politeknik Negeri Bandung.

Jesus Larralde (2011). Structural Analysis of Rigid

Pavements With Pumping, School of Civil

Engineering Indiana Department of

Highways. 
Luh M. Chang, Yu Tzu Chen dan Sangwook Lee. (2004). Using Precast Concrete Panels For Pavement Contruction In Indiana.

Lynn Evan, Tom Pyle, Walid Tabet. (2005). Evaluation Of Polyurathene Foam Supporting Existing Rigid Concrete Pavement Slabs.

Miller, M.M (1958)., Stresses and Deflecnons In Continuously Reinforced Concrere Paventents., Joint Highway Research Project, Purdue University Lafayette Indiana.

Mulyani Sri. (2010). Stabilisasi Tanah Lempung dengan Bahan Tambah Abu Terbang Limbah Pembakaran Batu Bara.

Ninik Ariyani dan Andriyanto C. Nugroho (2007) "Pengaruh Kapur dan Abu Sekam Padi pada Nilai CBR Laboratorium Tanah Tras dari Dusun Seropan untuk Stabilitas

Santoso Nurcahyo B. (2003). Teknik Pelaksanaan Jalan Beton.

Sukirman,S.,1995,” Perkerasan Lentur Jalan Raya, Penerbit Nova , Bandung

Westergaard, H. (1926) "Stresses in concrete pavements computed by theoretical analysis, public roads, PP.23-35

Winda Sekar Putri, Harimurti, Suroso (undated), Pengaruh variasi Beban terhadap perilaku tegangan dan lendutan tanah ekspansif di bawah perkerasan kaku, Jurusan Teknik Sipil Fakultas Teknik Universitas Brawijaya

Youn su Jung, Dan G. Zollinger, Moon Won, and Andrew J. Wimsatt (2009)., Subbase and Subgrade Performance Investigation For Concrete Pavement, Texas Trtnsportation Institute The Texas A\&M University System. *) Staf Pengajar POLBAN 